\title{
Apoptosis-Mediated Cytotoxicity of Prodigiosin-Like Red Pigment Produced by $\gamma$-Proteobacterium and Its Multiple Bioactivities
}

\author{
Takuji Nakashima, ${ }^{*}, a, b$ Tadashi Tamura, ${ }^{a}$ Maki Kurachi,${ }^{a}$ Kenichi Yamaguchi, ${ }^{a}$ and Tatsuya OdA ${ }^{a}$ \\ ${ }^{a}$ Division of Biochemistry, Faculty of Fisheries, Nagasaki University; 1-14 Bunkyo-machi, Nagasaki 852-8521, Japan: \\ and ${ }^{b}$ Nagasaki Prefecture Collaboration of Regional Entities for the Advancement of Technological Excellence, JST; \\ 2-1308-8 Ikeda, Omura, Nagasaki 856-0026, Japan. \\ Received May 3, 2005; accepted October 2, 2005; published online October 4, 2005
}

Recently we discovered a bacterial strain (MS-02-063) that produces large amounts of red pigment (PG-L1). Among the cell lines tested, U937 cells showed the highest susceptibility to PG-L-1 toxicity. PG-L-1 induced typical apoptotic nuclear morphological changes, and single cell gel electrophoresis revealed that PG-L-1 caused DNA fragmentation in U937 cells. In PG-L-1 treated U937 cells, the acidic compartment such as lysosomes disappeared, suggesting that PG-L-1-induced disorder of intracellular pH compartmentalization might trigger apoptotic signal. Since p38 MAP kinase inhibitor specifically prevented the PG-L-1 mediated cell death, p38 MAP kinase may be involved in the cytotoxic mechanism. In fact, immunoblot analysis of p38 MAP kinase revealed that phosphorylation of p38 MAP kinase occurred in PG-L-1-treated U937 cells. In addition to the activity to induce apoptotic cell death as reported in several PG family members, our chemiluminescence analysis suggested that PG-L-1 inhibited superoxide generation by 12-O-tetradecanoylphorbol-13-acetate (TPA)-stimulated U937 cells in a dose-dependent manner. Since PG-L-1 had no effect on the chemiluminescence response caused by xanthine oxidase/hypoxanthine system, PG-L-1 acts on the enzyme system responsible for $\mathrm{O}_{2}^{-}$generation rather than direct scavenging toward $\mathrm{O}_{2}^{-}$. Our results suggest that PG-L-1 causes multiple biochemical effects on the target cells such as increase in $\mathrm{pH}$ in acidic intracellular compartment, activation of p38 MAP kinase, inhibition of $\mathrm{O}_{2}^{-}$generation, and eventually induces apoptotic cell death.

Key words prodigiosin; apoptosis; superoxide; U937 cell; $\gamma$-proteobacterium

A bacterial strain (MS-02-063), which produces red pigment, was discovered from our library established with more than 20000 microorganisms isolated from coastal area of Nagasaki prefecture, Japan. Comparison of $16 \mathrm{~S}$ rDNA gene sequence of strain MS-02-063 with sequences from GenBank demonstrated that this strain belongs to the $\gamma$-proteobacterium species. Recent our study has demonstrated that the highly purified red pigment showed potent antimicrobial activity against pathogenic microorganisms such as Staphylococcus aureus and dermatophytes. ${ }^{1)}$

Prodigiosin (PG) analogues belonging to a family of natural red pigments are characterized by a common pyrrolydipyrrolylmethene skeleton structure with a C-4 methoxy group, and several PG-like pigments have been isolated from certain microorganisms ${ }^{2-4)}$ including some genera of actinomycetes, Pseudoalteromonas denitrificans, and Serratia marcescens. Representative members of PG analogues are prodigiosin, undecylprodigiosin, cycloprodigiosin hydrochloride, metacycloprodigiosin, and nonylprodigiosin. ${ }^{5)}$ Some of PG analogues have been reported to have several biological activities such as immunosuppressive, antimalarial, antimicrobial and cytotoxic activities. ${ }^{6-11)}$ Although the exact cytotoxic mechanisms of PG family members are not fully clarified yet, apoptotic mechanism has been proposed for some PG analogues. For instance, it has been reported that cycloprodigiosin hydrochloride induces apoptosis in cancer cells both in vitro and in vivo, with high efficiency in liver cancer, breast cancer cell lines, and colon cancer cells, ${ }^{12-14)}$ with no apparent toxicity to normal cells. ${ }^{14)}$ PG produced by $S$. marcescens also induces apoptosis in haematopoietic and gastrointestinal cancer cell lines, but no marked toxicity to non-malignant cell lines. ${ }^{7,15,16)}$ Considering the high selectivity of PG family members to cancer cells, these pigments may be promising candidates for new anticancer drugs with unique action mechanism. Regarding the structure-activity relationship, it has been reported that a nitrogen-containing heterocyclic A-pyrrole ring with the lone-pair nitrogen electrons in conjugation with the tricyclic frame and a C-4 alkoxy are important for the biological activities of PG analogues. ${ }^{17)}$

Although there are extensive studies on the cytotoxicities of PG analogues produced by $S$. marcescens and P. denitrificans, ${ }^{4,16)}$ only limited information on the bioactivities of PG analogues produced by $\gamma$-proteobacterium is available. In this study, we examined the cytotoxic effects of PG analogue (PG-L-1), produced by $\gamma$-proteobacterium (strain MS-02063 ) on various cultured cell lines. Since U937 cells showed the highest susceptibility to PG-L-1 cytotoxicity, we conducted detailed analysis of cytotoxic mechanism of PG-L-1 in U937 cells especially in terms of apoptotic cell death. To search for new aspect of biochemical activity of PG-L-1, we also examined the effect of PG-L-1 on the $\mathrm{O}_{2}^{-}$generation by $12-O$-tetradecanoylphorbol-13-acetate (TPA)-stimulated U937 cells.

\section{MATERIALS AND METHODS}

Materials A specific p38 MAPK inhibitor (SB203580), extracellular signal-regulated kinase (ERK) inhibitor, PD98059, and xanthine oxidase (buttermilk, $10 \mathrm{U}$ ) were obtained from Calbiochem (La Jolla, CA, U.S.A.). JNK MAPK inhibitor, SP-600125, was obtained from Funakoshi Co., Ltd. (Tokyo, Japan). H33258 (Hoechst 33258), Cu/Zn superoxide dismutase (SOD, bovine erythrocytes), and hypoxanthine were purchased from Wako Chemical Co. (Tokyo, Japan), and acridine orange was purchased from Sigma Chemical 
Co. (St. Louis, MO, U.S.A.).

Preparation of Red Pigment (PG-L-1) and Prodigiosin Produced by Serratia marcescens JCM 1239 PG-L-1 was purified from strain MS-02-063 as described by Nakashima et al. ${ }^{1)}$ The pigment was dissolved in methanol to give a stock solution of $10 \mathrm{mg} / \mathrm{ml}$, and was stored in dark at $-80^{\circ} \mathrm{C}$. Serratia marcescens JCM 1239 that produces prodigiosin $\left(\mathrm{PG}^{\mathrm{ser}}\right)$ was obtained from Riken Cell Bank (Tsukuba, Ibaragi, Japan). S. marcescens JCM 1239 was cultivated in yeast extract-peptone-glucose (YPG) agar medium containing $12.5 \mathrm{~g}$ of yeast extract, $12.5 \mathrm{~g}$ of peptone, $30 \mathrm{~g}$ of glucose, and $15 \mathrm{~g}$ agar per liter at $28^{\circ} \mathrm{C}$ for $48 \mathrm{~h}$ because this strain did not produce pigment when it was cultured in broth medium. $S$. marcescens cells grown on the agar surface were then harvested with a scraper. $\mathrm{PG}^{\text {ser }}$ was extracted by shaking the $S$. marcescens cells with a mixture of methanol/1 N $\mathrm{HCl}$ $(24: 1)$, and purified as previously described. ${ }^{16)}$ In reversedphase high performance liquid chromatography (HPLC), ODS C-18 column $(4.6 \times 250 \mathrm{~mm}$, Finepak SIL 300C18T-7 JASCO, Tokyo, Japan) was used with the following mobile phase; buffer A was $0.01 \mathrm{~m}$ ammonium acetate, buffer $\mathrm{B}$ was $100 \%$ methanol. After a 5-min flow with $100 \%$ buffer A, a 30 -min linear gradient to $100 \%$ buffer B was run at a flow rate of $1 \mathrm{ml} / \mathrm{min}$. Analysis of PG-L-1 and $\mathrm{PG}^{\text {ser }}$ were performed with 3 dimensional (3D) chromatogram by Millennium $^{32}$ PDA Software (Waters, Co., Milford, MA, U.S.A.).

Cell Culture Madin-Darby canine kidney (MDCK), chinese hamster ovary (CHO), human epithelial carcinoma (HeLa), green monkey kidney (Vero), human myeloid leukemia (U937) cells were obtained from Riken Cell Bank (Tsukuba, Ibaragi, Japan). Rat sarcoma (XC) and potoroo rat kangaroo kidney $\left(\mathrm{PtK}_{1}\right)$ cells were obtained from the American Type Culture Collection (Rockville, MD, U.S.A.). These cells except U937 cells were grown as monolayer in $\alpha$-minimum essential medium ( $\alpha$-MEM) containing $10 \%$ fetal bovine serum (FBS), penicillin $\mathrm{G}(100 \mu \mathrm{g} / \mathrm{ml})$, and streptomycin $(100 \mu \mathrm{g} / \mathrm{ml})$. The cells were subcultured $1 \mathrm{~d}$ before use by treatment with $0.1 \%$ trypsin- $0.05 \%$ EDTA in phosphatebuffered saline (PBS). U937 cells in suspension culture were routinely maintained in RPMI 1640 supplemented with $10 \%$ FBS, penicillin $\mathrm{G}(100 \mu \mathrm{g} / \mathrm{ml})$, and streptomycin $(100 \mu \mathrm{g} /$ $\mathrm{ml})$.

Cytotoxicity Assays The cytotoxicity of PG-L-1 against adherent cell lines was determined by colony formation assay. In this assay, cells were inoculated at a density of 200 cells/well in $200 \mu \mathrm{l}$ of medium on 48 -well plates. One day later, various concentrations of PG-L-1 were added to the cells followed by incubation for $5 \mathrm{~d}$ at $37^{\circ} \mathrm{C}$. After removal of the medium containing PG-L-1, $1 \%$ methylene blue in $50 \%$ methanol was added to each well and incubated for 5 min at room temperature. Numbers of colony stained with methylene blue were counted. In the case of U937 cells, alamar blue assay was employed. U937 cells (100 $\mu \mathrm{l})$ were inoculated into each well of 96-well plates at a density of $2 \times 10^{4}$ cells/well. Various concentrations of samples were added to the cells followed by incubation at $37^{\circ} \mathrm{C}$ for $24 \mathrm{~h}$. Alamar blue reagent was added to the medium at $10 \%$ final concentration. After $1 \mathrm{~h}$ incubated at $37^{\circ} \mathrm{C}$, the differences in absorbance at $570 \mathrm{~nm}$ and $600 \mathrm{~nm}$ were measured by MPRA4i2 microplate reader (Tosoh Co., Tokyo, Japan).

Nuclear Staining Nuclear morphological changes were examined by staining with the DNA-binding fluorochrom bisbenzimide (Hoechst 33258) as described previously. ${ }^{18)}$ PG-L-1 $(0.1,1.5$, and $50 \mu \mathrm{g} / \mathrm{ml}$ as final concentrations) was added to U937 cells growing in $35 \mathrm{~mm}$ dishes and incubated in RPMI 1640 containing 10\% FBS. After $3 \mathrm{~h}$ incubation at $37^{\circ} \mathrm{C}$, the cells were stained with Hoechst $33258(40 \mu \mathrm{M})$ for $10 \mathrm{~min}$ at room temperature, and observed with a fluorescence microscope (Axiovert 200; Carl Zeiss, Inc., Jena, Germany).

Single Cell Gel Electrophoresis Assay (Alkaline Comet Assay) The alkaline comet assay was performed according to methods described previously. ${ }^{19,20)}$ U937 cells $\left(2 \times 10^{6}\right.$ cells/dish, $35 \mathrm{~mm}$ ) in RPMI 1640 containing 10\% FBS were treated with PG-L-1 $(0.1,1.5$, and $50 \mu \mathrm{g} / \mathrm{ml}$ as final concentrations) at $37^{\circ} \mathrm{C}$. Each microscope slide was precoated with a layer of $0.75 \%$ normal melting point agarose (Nacalai Tesque, Inc., Kyoto, Japan) and thoroughly dried at room temperature. Next, $100 \mu \mathrm{l}$ of $0.5 \%$ low melting point agarose at $37^{\circ} \mathrm{C}$ was mixed with $10 \mu \mathrm{l}$ of the PG-L-1-treated cell suspension or untreated cell suspension. Seventy-five microliters of the agarose-cell mixture was dropped on top of the slide with normal melting point agarose layer. The slides were allowed to solidify for 2 min on ice and were then immersed in lysis solution $(2.5 \mathrm{~m} \mathrm{NaCl}, 100 \mathrm{~mm}$ EDTA, $10 \mathrm{~mm}$ Tris, $1 \%$ $\mathrm{Na}$ sarcosinate, $1 \%$ Triton $\mathrm{X}-100,10 \%$ dimethylsulfoxide, $\mathrm{pH} 10.0$ ) at $4{ }^{\circ} \mathrm{C}$ for $1 \mathrm{~h}$. After lysis, the slides were placed in a horizontal gel electrophoresis chamber filled with fresh, chilled electrophoresis buffer $(300 \mathrm{~mm} \mathrm{NaOH}$ and $1 \mathrm{~mm}$ EDTA, pH 13.0) to a level of approximately $2.5 \mathrm{~mm}$ above the slides. To allow the unwinding of the DNA, the slides were exposed to high $\mathrm{pH}$ buffer for $20 \mathrm{~min}$. Electrophoresis was then carried out for $20 \mathrm{~min}$ at $25 \mathrm{~V}$. Then the slides were rinsed three times with neutral solution $(0.4 \mathrm{M}$ Tris- $\mathrm{HCl}$ buffer, $\mathrm{pH} 7.5$ ) each for $5 \mathrm{~min}$ and stained with $50 \mu \mathrm{l}$ of ethidium bromide $(20 \mu \mathrm{g} / \mathrm{ml})$ and covered with a coverslip for immediate analysis. A total of 100 cells per a slide were observed at each dose point by Comet Imager ${ }^{\mathrm{TM}} \mathrm{V} 1.2$ (Carl Zeiss, Inc.). Observations were made at a magnification of 200 using a fluorescence microscope (Carl Zeiss, Inc.). The extent of DNA migration in each cell was determined using the software package, and tail moment was calculated as the parameter.

Effect of MAPK Inhibitors on the Cytotoxicity of PGL-1 in U937 Cells To study the effects of SAPK/JNK, ERK and p38 MAPK inhibitors on the cytotoxicity of PG-L1 , U937 cells grown in 96 well plate $\left(2 \times 10^{4}\right.$ cells/well $)$ were incubated in RPMI 1640 containing $10 \%$ FBS and $10 \mu \mathrm{M}$ each inhibitor for $2 \mathrm{~h}$, and then cells were treated with various concentrations of PG-L-1. The viability of each treated cells was measured by alamar blue assay as described above.

Immunoblot Analysis of Phosphorylated and Total p38 MAP Kinase in PG-L-1-Treated U937 Cells Cells $(2 \times$ $10^{6}$ cells/dish, $35 \mathrm{~mm}$ ) in RPMI 1640 containing 10\% FBS were treated with PG-L-1 $(0.1,1.5$, and $50 \mu \mathrm{g} / \mathrm{ml}$ as final concentrations) at $37^{\circ} \mathrm{C}$. After $30 \mathrm{~min}$ or $3 \mathrm{~h}$ incubation, the cells were washed twice with PBS and pelleted by centrifugation. The pelleted cells were resuspended in $100 \mu \mathrm{l}$ of extraction buffer (10 mM HEPES, $150 \mathrm{~mm} \mathrm{NaCl}, 1 \mathrm{~mm} \mathrm{NaCl}$, $1 \mathrm{~mm}$ EGTA, 1\% CHAPS, $1 \mathrm{~mm}$ phenylmethylsulfonyl fluoride, $10 \mathrm{~mm}$ aprotinin, $10 \mathrm{~mm}$ leupeptin, $10 \mathrm{~mm}$ pepstatin, $\mathrm{pH}$ 7.4), and then sonicated for $2 \mathrm{~min}$ at $4^{\circ} \mathrm{C}$. Following centrifu- 
gation $\left(21000 \times \boldsymbol{g}\right.$ for $10 \mathrm{~min}$ at $\left.4{ }^{\circ} \mathrm{C}\right)$, the extract was mixed with the equal volume of SDS-sample buffer (1\% SDS, $1 \%$ 2-mercaptoethanol, $10 \mathrm{~mm}$ Tris- $\mathrm{HCl}, \mathrm{pH} 6.8,5 \%$ glycerin) and boiled for $5 \mathrm{~min}$. Samples containing $50 \mu \mathrm{g}$ of protein were subjected to SDS-PAGE in a $15 \%$ polyacrylamide gel. The proteins were then transferred to a PVDF membrane. Western blotting was performed with antibodies recognizing phosphorylated p38 MAP kinase (Boehringer Mannheim, Mannheim, Germany) and total p38 MAP kinase (Santa Cruz, CA, U.S.A.), and suitable peroxidase-conjugated secondary antibodies (Amersham Pharmacia Biotech, Buckinghamshire, U.K.).

Fluorescent Vital Staining of Intracellular Acidic Compartments To examine the effects of PG-L-1 on the intracellular acidic compartments, U937 cells were stained with acridine orange as previously described. ${ }^{21)}$ Cells $\left(2 \times 10^{6}\right.$ cells/dish, $35 \mathrm{~mm}$ ) in RPMI 1640 containing 10\% FBS were treated with PG-L-1 $(0.1,1.5$, and $50 \mu \mathrm{g} / \mathrm{ml}$ as final concentrations) at $37^{\circ} \mathrm{C}$ for $1 \mathrm{~h}$. After the treatments, cells were collected and pelleted by centrifugation $(1500 \times \boldsymbol{g}$ for $5 \mathrm{~min})$, and the supernatant was removed. The cells were washed with PBS and subsequently incubated with $5 \mu \mathrm{g} / \mathrm{ml}$ acridine orange in PBS for $10 \mathrm{~min}$ at room temperature. The cells were washed with PBS, and then observed with a fluorescence light microscopy (Carl Zeiss, Inc.).

Effect of PG-L-1 or PG ${ }^{\text {ser }}$ on the Superoxide Generation in TPA-Stimulated U937 Cells U937 cells were harvested and washed twice with sterile phosphate-buffered saline (PBS) by centrifugation. The cells were suspended in Krebs-Ringer phosphate buffer (KRP) containing $11 \mathrm{~mm}$ glucose ( $\mathrm{pH} 7.4)$. To the cell suspension in 96-well white microplate (Dynex Microlite ${ }^{\mathrm{TM}}$ 1; Dynex Technologies, Chantilly, VA, U.S.A.) $\left(5 \times 10^{5}\right.$ cells/well $)$, chemiluminescence probe, L-012 (final $10 \mu \mathrm{M}$ ), various concentrations of PG-L$1, \mathrm{PG}^{\text {ser }}$, or superoxide dismutase (final $10 \mathrm{U}$ ) were added at the same time. After $3 \mathrm{~min}$ incubation at $37^{\circ} \mathrm{C}$, the reaction was started by the addition of final $1 \mu \mathrm{g} / \mathrm{ml}$ of TPA. During the incubation, chemiluminescence response was recorded continuously for $30 \mathrm{~min}$ using chemiluminescence microplate recorder (Mithras LB940, Berthold Technologies GmbH and Co. KG., Bad Wildbad, Germany). To superoxide generation system that consisted of $50 \mathrm{~mm}$ Tris- $\mathrm{HCl}$ buffer pH 7.4, 0.6 mм EDTA, L-012 (final $50 \mu \mathrm{m}$ ), and xanthine oxidase (final $5 \mathrm{mU}$ ), $2 \mu \mathrm{g} / \mathrm{ml}$ of PG-L-1 or PG $^{\text {ser }}$ was added. After $0.7 \mathrm{~min}$ preincubation at $37^{\circ} \mathrm{C}$, hypoxanthine (final $500 \mu \mathrm{M})$ was added to the reaction mixture to initiate the superoxide generation. During the incubation, the chemiluminescence response of each well was recorded continuously for $5.7 \mathrm{~min}$ as described above.

Statistical Analysis Data were expressed as mean \pm S.D., and analyzed with $t$-test. $p<0.05$ was considered to be significant.

\section{RESULTS}

Purification of PG-L-1 Purifies of PG-L-1 and PG ${ }^{\text {ser }}$ were analyzed by $3 \mathrm{D}$ chromatogram using Millennium ${ }^{32}$ PDA Software (Waters Co.). As shown in Fig. 1, PG-L-1 showed a major single peak with same retention time of $\mathrm{PG}^{\mathrm{ser}}$, and there was also similarity in the absorption spectra between these pigments. Therefore, it is suggested that PG-
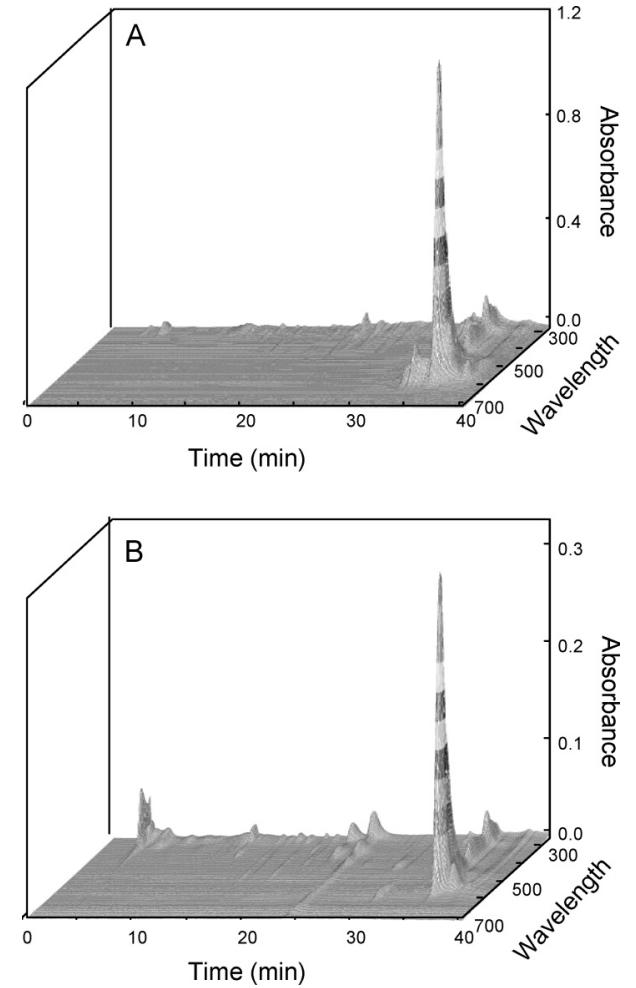

Fig. 1. Three-Dimensional HPLC Chromatographic Analysis of PG-L-1 from Strain MS-02-063 and Prodigiosin ( $\mathrm{PG}^{\text {ser }}$ ) from Serratia marcescens JCM 1239

The same concentration $(10 \mathrm{mg} / \mathrm{ml})$ of PG-L-1 (A) and PG ${ }^{\text {ser }}(B)$ were eluted with a linear gradient system consisting of $0.01 \mathrm{~m}$ ammonium acetate and $100 \%$ methanol.

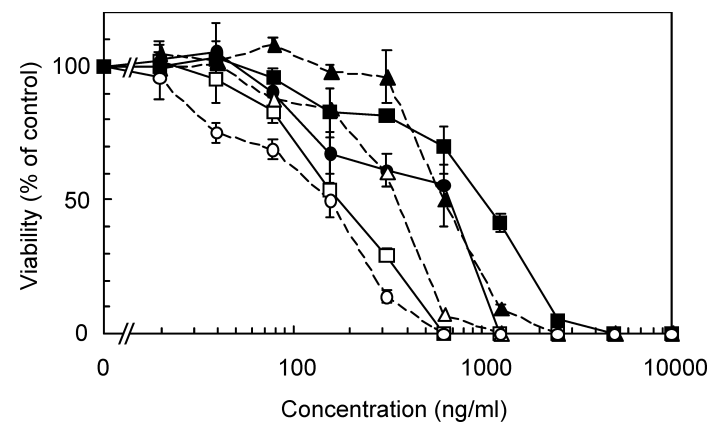

Fig. 2. Dose-Response Curves of the Cytotoxicity of PG-L-1 to HeLa $(\bigcirc), \mathrm{XC}(\triangle), \mathrm{CHO}(\square), \operatorname{MDCK}(\bullet)$, Vero $(\boldsymbol{\Delta})$, and $\mathrm{PtK}_{1}(\boldsymbol{\square})$ Cells

The cytotoxicity of PG-L-1 was measured by the inhibition of colony formation. Adherent cells ( 200 cells/well in 48 -well plate) were cultured with varying concentrations of PG-L-1 in $\alpha$-MEM medium supplemented with $10 \%$ FBS, pH 7.4 at $37^{\circ} \mathrm{C}$ for $5 \mathrm{~d}$, then the numbers of colonies formed were counted as described in Materials and Methods. Error bars represent standard deviation.

L-1 has the basic structure of prodigiosin.

Cytotoxicity of PG-L-1 against Various Cell Lines Cytotoxicity of PG-L-1 against MDCK, CHO, HeLa, Vero, XC, and $\mathrm{PtK}_{1}$ cells was measured by colony formation assay. As shown in Fig. 2, PG-L-1 showed potent cytotoxicity against all cell lines tested in a concentration-dependent manner. $\mathrm{HeLa}$ cells and $\mathrm{CHO}$ cells showed relatively higher sensitivity, and the $\mathrm{ED}_{50}$ of these cells were estimated to be $150 \mathrm{ng} /$ $\mathrm{ml}$, while MDCK, Vero, and $\mathrm{PtK}_{1}$ cells were slightly resistance to PG-L-1. Although the assay method is different, U937 cells were highly sensitive to PG-L-1, and the $\mathrm{ED}_{50}$ value was estimated to be $70 \mathrm{ng} / \mathrm{ml}$ by alamar blue assay 
(Fig. 3). $\mathrm{PG}^{\text {ser }}$ also showed potent cytotoxicity to U937 cells, and the dose-response curve was similar to that of PG-L-1 (Fig. 3).

Morphological Changes in U937 Cells After $3 \mathrm{~h}$ incubation with PG-L-1 at $37^{\circ} \mathrm{C}$, significant part of U937 cells were morphologically changed (Figs. 4C, D). Furthermore, fluorescent nuclear staining with Hoechst 33258 revealed that PG-L-1 induced typical apoptotic nuclear morphological changes in a concentration-dependent manner (Figs. 4E-H).

PG-L-1 Induced DNA Fragmentation in U937 Cells To further clarify the induction of apoptosis by PG-L-1, single cell gel electrophoresis assay (alkaline comet assay) was conducted in PG-L-1-treated U937 cells to estimate the degree of DNA fragmentation. Fig. 5 shows typical apoptotic nucleus patterns comprising a head and a tail, and a comet image was seen in PG-L-1-treated cells. The PG-L-1 induced a significant increase in the tail area in a concentration-dependent manner. Based on these patterns, the percentage of apoptotic cells in U937 cells treated with $0.1,1.5$, and $50 \mu \mathrm{g} /$ $\mathrm{ml}$ of PG-L-1 was estimated to be $29.1,58.8$, and $96.0 \%$, respectively (Fig. 6A). The tail moment values in PG-L-1treated cells, which reflect the extent of DNA fragmentation, also increased in a concentration-dependent manner (Fig. 6B).

Activation of p38 MAP Kinase in PG-L-1-Treated U937 Cells It has been known that members of the mitogen activated protein kinase (MAP kinase) family are involved in

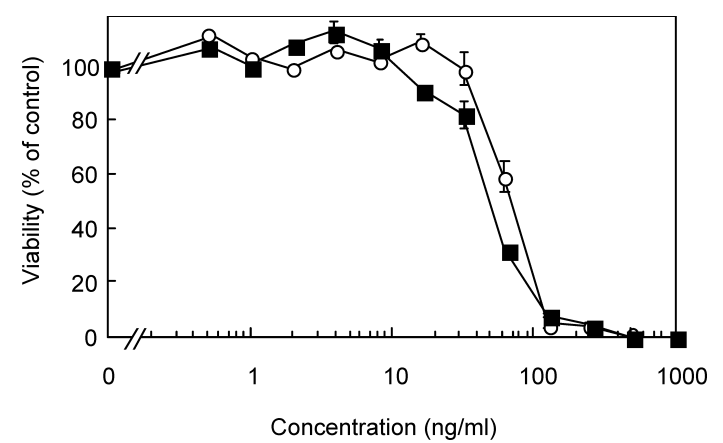

Fig. 3. Cytotoxicity of PG-L-1 $(\bigcirc)$ and $\mathrm{PG}^{\text {ser }}(\boldsymbol{\square})$ against U937 Cells

Varying concentrations of PG-L- 1 or PG ${ }^{\text {ser }}$ were added to the cells $\left(2 \times 10^{4}\right.$ cells/well $)$ in RPMI 1640 medium containing $10 \%$ FBS. After $24 \mathrm{~h}$ at $37^{\circ} \mathrm{C}$, the viabilities of each treated cells were measured by alamar blue assay as described in Materials and Methods. Error bars represent standard deviation.
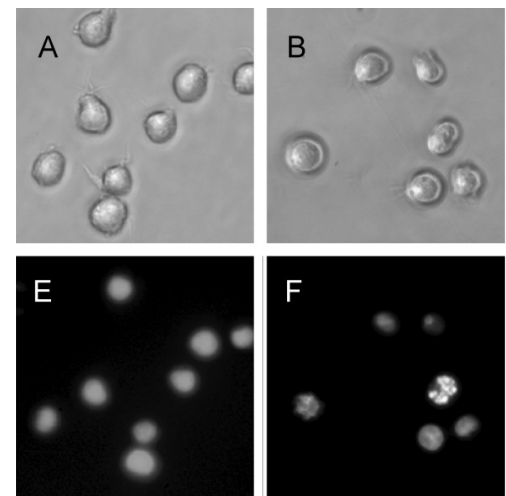

the signal transduction pathways in the regulation of cell survival. Extracellular signal-regulated kinases (ERKs) are activated by growth factor stimulation, while the stress activated protein kinase (SAPK)/c-jun $N$-terminal kinase (JNK) and p38-MAP kinase (p38-MAPK) are activated by various extracellular stresses. To study the involvement of MAP kinase cascade in PG-L-1-mediated cytotoxicity, we examined the effects of three specific MAP kinase inhibitors on the cytotoxicity of PG-L-1 in U937 cells. As shown in Fig. 7, the cytotoxicity of PG-L-1 was significantly inhibited by p38 inhibitors but not SAPK/JNK and ERK inhibitors, suggesting that $\mathrm{p} 38$ MAP kinase may play an important role in PG-L-1mediated cytotoxic mechanism. In agreement with this notion, Western blot analysis using specific antibodies against phosphorylated p38 MAP kinase demonstrated that activation of p38 MAP kinase occurred in a concentration-dependent manner in PG-L-1-treated U937 cells without significant changes in the levels of total p38 MAP kinase (Fig. 8).

Effects of PG-L-1 on the Intracellular Acidic Compartments in U937 Cells Effects of PG-L-1 on the intracellular acidic compartments in U937 cells were examined by vital staining with acridine orange. When normal U937 cells were


Fig. 5. Single Cell Gel Electrophoresis Assay (Alkaline Comet Assay) for PG-L-1-Treated U937 Cells

U937 cells grown in $35 \mathrm{~mm}$ dishes $\left(6 \times 10^{5}\right.$ cells/dish) were treated with $0 \mu \mathrm{g} / \mathrm{ml}$ (A), $0.1 \mu \mathrm{g} / \mathrm{ml}$ (B), $1.5 \mu \mathrm{g} / \mathrm{ml}$ (C), and $50 \mu \mathrm{g} / \mathrm{ml}$ (D) of PG-L-1 in RPMI containing $10 \%$ FBS at $37^{\circ} \mathrm{C}$ for $3 \mathrm{~h}$, and then the cells were subjected to gel electrophoresis as described in Materials and Methods. The bar indicates $10 \mu \mathrm{m}$.
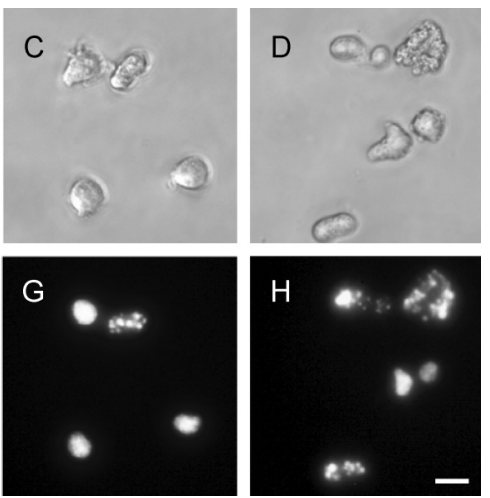

Fig. 4. Effect of PG-L-1 on Cellular and Nuclear Morphology in U937 Cells

U937 cells grown in $35 \mathrm{~mm}$ dishes $\left(6 \times 10^{5}\right.$ cells/dish) were treated with $0 \mu \mathrm{g} / \mathrm{ml}$ (A, E), $0.1 \mu \mathrm{g} / \mathrm{ml}(\mathrm{B}, \mathrm{F}), 1.5 \mu \mathrm{g} / \mathrm{ml}(\mathrm{C}, \mathrm{G})$, and $50 \mu \mathrm{g} / \mathrm{ml}(\mathrm{D}, \mathrm{H})$ of PG-L-1 in RPMI containing $10 \%$ FBS at $37^{\circ} \mathrm{C}$ for $3 \mathrm{~h}$, and then the cells were observed under a phase contrast microscope (A, B, C, D), or a fluorescence microscope (E, F, G, H) after stained with Hoechst $33258(40 \mu \mathrm{M})$ for $10 \mathrm{~min}$. The bar indicates $10 \mu \mathrm{m}$. 

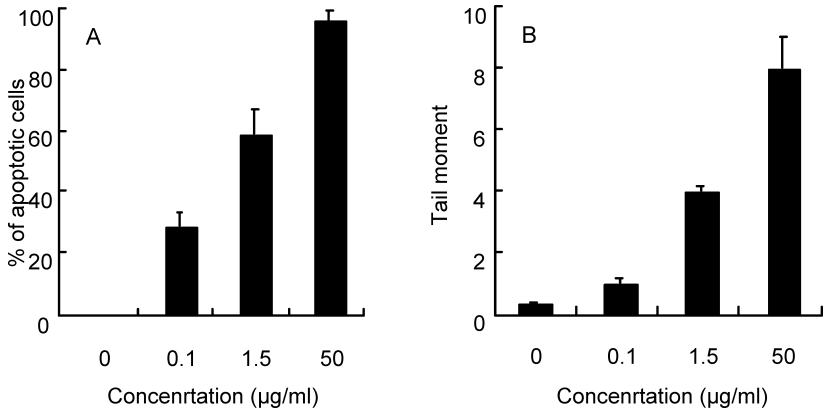

Fig. 6. The Population of Apoptotic U937 Cells and the Mean Values of Tail Moment Detected by the Comet Assay after Treatment with Varying Concentrations of PG-L-1

Based on the results of Fig. 5 in which the cells with comet shape were considered as apoptotic cells, the numbers of apoptotic cells based on total 100 cells were counted. Error bars represent standard deviation. (B) The mean values of tail moment of each cell, which reflect the extent of DNA fragmentation, for total 100 cells were measured.

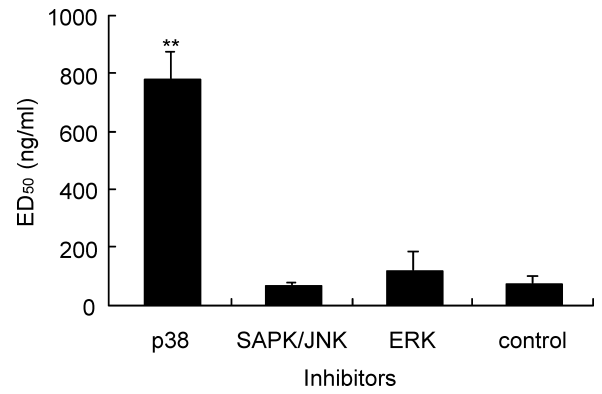

Fig. 7. Effect of MAP Kinase Inhibitors on the Cytotoxicity of PG-L-1 in U937 Cells

U937 cells were preincubated with $10 \mu \mathrm{M}$ each MAP kinase inhibitor in RPMI containing $10 \%$ FBS for $2 \mathrm{~h}$ at $37^{\circ} \mathrm{C}$, and then varying concentrations of PG-L-1 were added to the cells. After $24 \mathrm{~h}$ incubation at $37^{\circ} \mathrm{C}, \mathrm{ED}_{50}$ values were estimated from the dose-response curves obtained by alamar blue assay as described in Materials and Methods. Error bars represent standard deviation. $* * p<0.01 v s$. control.

stained with acridine orange, nuclei showed intense green fluorescence, and granular orange fluorescence was observed in the cytoplasm. Since acridine orange is known to produce orange fluorescence in the acidic environment, the orange fluorescence may reflect acidic lysosomes. In the PG-L-1treated cells, the region with orange fluorescence disappeared, and this effect of PG-L-1 was evident even at low concentration of PG-L-1 $(0.1 \mu \mathrm{g} / \mathrm{ml})$ (Fig. 9). These results suggest that PG-L-1 is capable to neutralize acidic compartment such as lysosomes which in turn may lead to disorder of intracellular acidic compartment.

Inhibitory Effect of PG-L-1 on Superoxide Generation by TPA-Stimulated U937 Cells When polymorphonuclear leukocytes are exposed to the appropriate stimuli such as TPA, NADPH oxidase is activated on the plasma membrane followed by $\mathrm{O}_{2}^{-}$production. ${ }^{22)}$ Superoxide generation in TPAstimulated U937 cells was analyzed by the chemiluminescence method. In addition to luminol, lucigenin, and MCLA which have been widely used as chemiluminescence probes for the determination of reactive oxygen species (ROS), ${ }^{23)} \mathrm{L}$ 012 is recently developed as a highly sensitive chemiluminescence probe. ${ }^{24)}$ Therefore, L-012 probe was used in this study. As shown in Fig. 10A, PG-L-1 showed inhibitory effect on the superoxide generation by TPA-stimulated U937 cells in a dose-dependent manner, whereas PG-L-1 had no



Fig. 8. PG-L-1 Induced Phosphorylation of p38 MAP Kinase in U937 Cells

U937 cells grown in $35 \mathrm{~mm}$ dishes $\left(6 \times 10^{5}\right.$ cells $/$ dish $)$ were treated with $0 \mu \mathrm{g} / \mathrm{ml}$ (control), $0.1 \mu \mathrm{g} / \mathrm{ml}, 1.5 \mu \mathrm{g} / \mathrm{ml}$, and $50 \mu \mathrm{g} / \mathrm{ml}$ of PG-L-1 in RPMI 1640 medium containing $10 \% \mathrm{FBS}$ at $37^{\circ} \mathrm{C}$ for $30 \mathrm{~min}(\mathrm{~A})$ or $3 \mathrm{~h}(\mathrm{~B})$, and then cell lysates were prepared for immunoblotting analysis with antibodies recognizing phosphorylated p38 MAP kinase (P-p38) and total p38 MAP kinase (p38) as described in Materials and Methods. This experiment was performed with two independent cultures to ensure the reproducibility of the results.
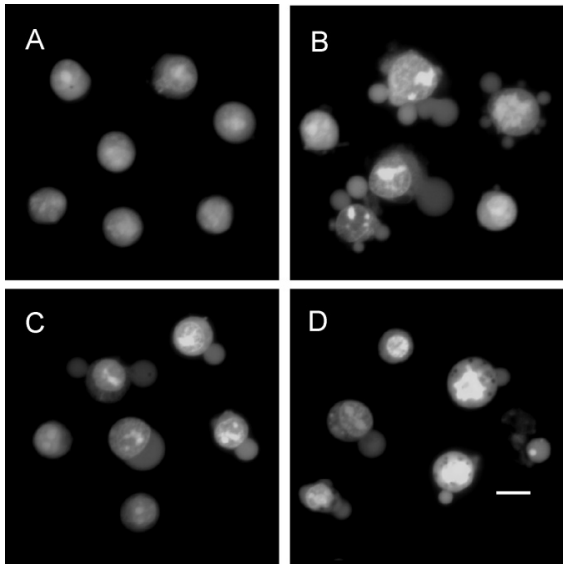

Fig. 9. Acridine Orange Staining of U937 Cells

U937 cells grown in $35 \mathrm{~mm}$ dishes $\left(6 \times 10^{5}\right.$ cells $/$ dish $)$ were treated with $0 \mu \mathrm{g} / \mathrm{ml}$ (A), $0.1 \mu \mathrm{g} / \mathrm{ml}$ (B), $1.5 \mu \mathrm{g} / \mathrm{ml}$ (C), and $50 \mu \mathrm{g} / \mathrm{ml}$ (D) of PG-L-1 in RPMI 1640 medium containing $10 \%$ FBS at $37^{\circ} \mathrm{C}$ for $1 \mathrm{~h}$, and then the cells were stained with $5 \mu \mathrm{g} / \mathrm{ml}$ acridine orange and observed under fluorescence microscope as described in Materials and Methods.

effect on the chemiluminescence response caused by xanthine oxidase/hypoxanthine system (Fig. 10B). On the other hand, no significant anti-superoxide generation of $\mathrm{PG}^{\text {ser }}$ was observed at the range of tested concentrations (Fig. 10A).

\section{DISCUSSION}

A marine bacterial strain, $\gamma$-proteobacterium (strain MS02-063), was found to produce a large amount of red pigment (PG-L-1). In this study, highly purified PG-L-1 was obtained from the culture supernatant of this bacterium by several chromatographic procedures. The yield of PG-L-1 from strain MS-02-063 was extremely higher than that of $S$. marcescens. Furthermore, strain MS-02-063 produced high amount of pigment even in the broth culture, whereas the pigment productivity of $S$. marcescens failed in broth culture. Thus strain MS-02-063 is suitable for the preparation of large amount of the prodigiosin pigment. The homogeneity of PGL-1 was confirmed by three-dimensional (3D) HPLC analysis (Fig. 1A). Namely the elution profile and retention time of PG-L-1 in HPLC were similar to those of PG ${ }^{\text {ser }}$ (Fig. 1B). 

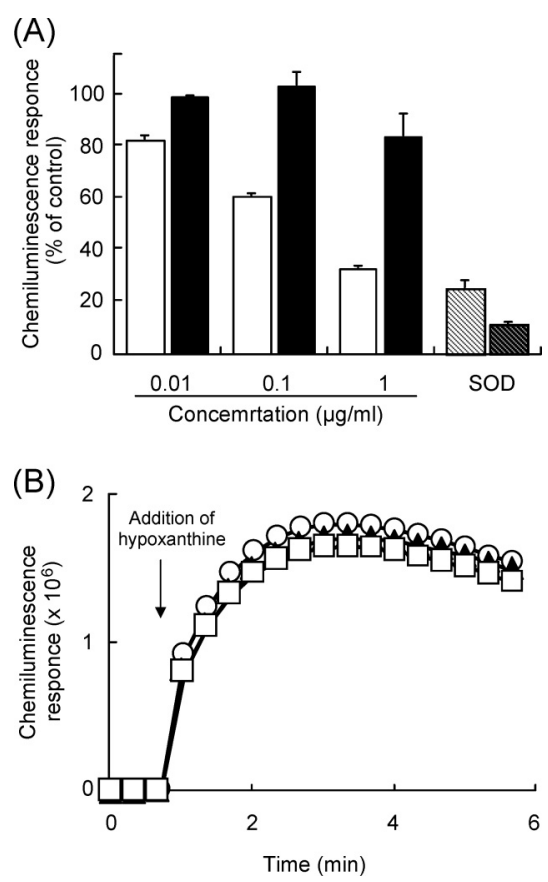

Fig. 10. Inhibitory Effect of PG-L-1 on Superoxide Generation in TPAStimulated U937 Cells

(A) The harvested U937 cells were suspended in Krebs-Ringer phosphate buffer containing $11 \mathrm{~mm}$ glucose $(\mathrm{pH} 7.4)$, and then the cell suspension was transferred into 96 well white microplate $\left(5 \times 10^{5}\right.$ cells/well). L-012 (final $\left.10 \mu \mathrm{M}\right)$ and various concentrations of PG-L-1 $(\square)$, PG $^{\text {ser }}(\mathbf{\square})$ or superoxide dismutase (SOD) ( $\mathbb{N} ; 1 \mathrm{U}, \mathbb{N} ; 10 \mathrm{U}$ ) were added to the wells at the same time. After incubation for $3 \mathrm{~min}$, TPA (fina $1 \mu \mathrm{g} / \mathrm{ml}$ ) was added to each well as a stimulant and then the chemiluminescence response was recovered for $30 \mathrm{~min}$ at $37^{\circ} \mathrm{C}$. (B) The scavenging effect on $\mathrm{O}_{2}^{-}$was measured by the chemiluminescence method in a reaction mixture consisted of $50 \mathrm{~mm}$ Tris$\mathrm{HCl}$ buffer, $\mathrm{pH} 7.4,0.6 \mathrm{~mm}$ EDTA, L-012 (final $50 \mu \mathrm{M}$ ), and xanthine oxidase (fina $5 \mathrm{mU}$ ), and then PG-L-1 $(\bigcirc)$ or PG ${ }^{\text {ser }}(\boldsymbol{\Delta})$ was added at final $1 \mu \mathrm{g} / \mathrm{ml}$. The $\mathrm{O}_{2}^{-}$generation was initiated by the addition of hypoxanthine (final $500 \mu \mathrm{M}$ ) to the reaction mixture. $(\square)$; control without pigment sample.

However, the absorbance of PG-L-1 at $533 \mathrm{~nm}$ was approximately 4 times higher than that of $\mathrm{PG}^{\mathrm{ser}}$ at the same concentration $(10 \mathrm{mg} / \mathrm{ml})$. Thus, it is considered that the number of chromophore in PG-L-1 molecule may be different from that of $\mathrm{PG}^{\mathrm{ser}}$ even if the entire structure is similar. Interestingly, the $\mathrm{ED}_{50}$ value of PG-L-1 in U937 cells was almost equal to that of $P^{\text {ser }}$ (Fig. 3). These results suggest that PG-L-1 is one of prodigiosin analogue with structural and bioactive similarity to $\mathrm{PG}^{\mathrm{ser}}$.

Comparable study using various cell lines indicated that U937 cells were highly sensitive to PG-L-1 cytotoxicity (Figs. 2, 3). To gain insight into the underlying cytotoxic mechanism of PG-L-1, the detailed analysis was conducted in U937 cells. As shown in Fig. 4, cellular morphological changes in U937 cells were induced by PG-L-1, and the population of cells with such changes increased as increased in the concentration of PG-L-1. Fluorescent nuclear staining with Hoechst 33258 revealed that PG-L-1 induced typical apoptotic nuclear morphological changes (Fig. 4). In addition, single cell comet assay indicated that PG-L-1 induces DNA fragmentation (Figs. 5, 6). Since PG analogues especially prodigiosin and cycloprodigiosin hydrochloride have been shown to induce apoptosis in several cancer cells, ${ }^{6,12,14,16,25)}$ the apoptosis-induction may be a common cytotoxic mechanism of PG analogues. Apoptosis is known as programmed cell death, and intracellular signal transduction is generally considered to be involved. Although the detailed mechanism of apoptosis-induction by PG analogues is remained to be clarified, following possible action mechanism of PG analogues have been reported. PG members are known to have multiple bioactivities such as (i) mitogen-activated protein (MAP) kinase regulator; (ii) intracellular $\mathrm{pH}$ modulator; (iii) direct DNA cleavage agent; (iv) cell cycle inhibitor. ${ }^{10)}$ Probably some of these actions or their combination may be responsible for the apoptosis induction. Since the cytotoxicity of PG-L-1 was effectively inhibited by specific p38 MAP kinase inhibitor but not by JNK and ERK kinase inhibitors (Fig. 7), p38 MAP kinase may play a crucial role in the PG-L-1-mediated apoptotic cell death. Furthermore, immunoblot analysis indicated that activation of $\mathrm{p} 38$ MAP kinase occurred in PG-L-1-treated U937 cells (Fig. 8). Regarding the involvement of MAP kinase activation, it has been reported that prodigiosin from $S$. marcescens induced phosphorylation of p38 MAP kinase but not of SAPK/JNK MAP kinase ${ }^{26)}$ whereas cycloprodigiosin hydrochloride from P. denitrificans activated SAPK/JNK MAP kinase to promote apoptosis. $^{27}$ Therefore, these findings suggest that some structural differences between these PG analogues may be partly attributable to the different bioactivities. PG-L-1 may be more similar to prodigiosin from $S$. marcescens rather than cycloprodigiosin hydrochloride from $P$. denitrificans in terms of the involvement of MAP kinase activation cascade. This notion may be supported by the fact that $\mathrm{ED}_{50}$ values of PG-L-1 and PG ${ }^{\text {ser }}$ in U937 cells were almost equal.

Some PG analogues have shown to behave as promoters of $\mathrm{H}^{+} / \mathrm{Cl}^{-}$symport that uncouples proton translocation and thereby perturbs vacuolar acidification including lysosome, thus inducing intracellular acidification and eventually apoptosis. $^{13,27-29)}$ In addition to PG analogues, some drugs such as bafilomycin A that is known to inhibit a variety of intracellular $\mathrm{pH}$ homeostatic mechanisms, lowered intracellular $\mathrm{pH}$ and thereby lead to apoptosis of cancer cells. ${ }^{30)}$ Therefore, the acidification of cytosol and/or the disruption of the $\mathrm{pH}$ gradient across the cytoplasmic membrane appear to be involved in triggering apoptosis especially in cancer cells. In fact, the vital staining of PG-L-1-treated U937 cells with acridine orange suggested that PG-L-1 affects the acidic compartment such as lysosomes. Therefore, one can speculate that PG-L-1 may perturb intracellular $\mathrm{pH}$ compartmentation by inhibition of the $\mathrm{H}^{+} / \mathrm{Cl}^{-}$symport and causes acidification of cytoplasm which may in turn lead to apoptosis. As another activity of PG family, Melvin et al. reported that synthetic prodigiosin could facilitate copper-promoted oxidative single and even double stranded DNA cleavage. This direct effect of synthetic prodigiosin on DNA is proposed as basic action mechanism responsible for the cytotoxicity of PG analogues. ${ }^{17)}$ However, no significant DNA cleavage was observed when isolated DNA was incubated with PG-L-1 at the cytotoxic concentration of PG-L-1 (data not shown). Therefore, it seems unlikely that direct attack of PG-L-1 on DNA is major trigger to induce apoptosis. Structure-activity relationship analysis using of some derivatives of synthetic prodigiosin demonstrated that the A-pyrrole ring of PGgroup plays a key role in both the copper-catalyzed DNA cleavage activity and cytotoxic potency. ${ }^{31)}$ In addition, replacement of the A-pyrrole ring with a thiophene group on synthetic prodigiosin molecule results in disappearance of the ability to promote strand-scission of supercoiled DNA in 
the presence of copper ${ }^{32)}$ and cytotoxicity. ${ }^{33)}$ The same effect is also achieved by attaching an electron-withdrawing substituent (acetyl group) to the 5'-position of the A-pyrrole ring. ${ }^{25)}$ Therefore, PG-L-1 molecule might have different structure from $\mathrm{PG}$ molecule at A-pyrrole ring.

Interestingly, PG-L-1 showed the inhibitory effect on superoxide generation by TPA-stimulated U937 cells in a dosedependent manner (Fig. 10A), whereas PG-L-1 had no direct scavenging activity against the superoxide generated by the xanthine oxidase/hypoxanthine system (Fig. 10B). Although PG-L-1 and PG $^{\text {ser }}$ showed almost equal cytotoxicity toward U937 cells, PG-L-1 had more potent inhibition effect on the superoxide generation than that of $\mathrm{PG}^{\mathrm{ser}}$. It has been well known that macrophage produces superoxide in response to extracellular stimuli through the activation of NADPH oxidase that involves the assembly of cytosolic components (e.g., p47-phox, p67-phox and Rac) and membrane-associated components (e.g., gp91-phox and p22-phox) to form an active NADPH oxidase enzyme complex in which is located the plasma membrane. ${ }^{34,35)}$ Therefore, it is speculated that PG-L-1 might directly act on NADPH oxidase or on the activation process of this enzyme. Although the extent of the inhibition of $\mathrm{O}_{2}^{-}$generation may differ each prodigiosin family members as seen in this study, this is the first report to demonstrate that prodigiosin family members can affect $\mathrm{O}_{2}^{-}$ generation system in macrophage. Further study is required to clarify the detailed action mechanism.

In conclusion, we found that PG-L-1 showed potent cytotoxicity especially against U937 cells. By the detailed analysis of the events occurred in PG-L-1-treated U937 cells, it was suggested that PG-L-1 induced apoptotic cell death through p38 MAP kinase activation cascade and disorder of intracellular acidic compartment. Furthermore, PG-L-1 showed marked inhibitory effects on TPA-induced superoxide generation in U937 cells in a dose-dependent manner. Thus, PG-L-1 is not only the potential candidate for cancer chemotherapeutic agent but also can be a tool to analyze cellular $\mathrm{O}_{2}^{-}$generation system. Further investigation of PG-L-1 may provide insight into the development of new drug for cancer chemotherapy and immunosuppressor with unique action mechanism.

\section{REFERENCES}

1) Nakashima T., Kato Y., Yamaguchi K., Oda T., J. Infect. Chemother, 11, 123-128 (2005).

2) Anuradha G., Nandini A., Geetha M., Gautam P., BMC Microbiol., 18, $11-20$ (2004).

3) Gerber N. N., Stahly D. P., Appl. Microbiol., 30, 807-810 (1975).

4) Kawauchi K., Shibutani K., Yagisawa H., Kamata H., Nakatsuji S., Anzai H., Yokoyama Y., Ikegami Y., Moriyama Y., Hirata H., Biochem. Biophys. Res. Commun., 237, 543-547 (1997).
5) Alois F., Angewandte Chemie, 42, 3582-3603 (2003).

6) Campas C., Dalmau M., Montaner B., Barragan M., Bellosillo B., Colomer D., Pons G., Perez-Tomas R., Gil J., Leukemia, 17, 746-750 (2003).

7) Diaz-Ruiz C., Montaner B., Perez-Tomas R., Histol. Histopathol., 16, 415-421 (2001).

8) Gerber N. N., CRC Crit. Rev. Microbiol., 3, 469-485 (1975).

9) Isaka M., Jaturapat A., Kramyu J., Tanticharoen M., Thebtaranonth Y., Antimicrob. Agents Chemother, 46, 1112-1113 (2002).

10) Montaner B., Perez-Tomas R., Curr. Cancer Drug Targets, 3, 57-65 (2003).

11) Ramoneda B. M., Perez-Tomas R., Biochem. Pharmacol., 63, 463469 (2002).

12) Soto-Cerrato V., Llagostera E., Montaner B., Scheffer G. L., PerezTomas R., Biochem. Pharmacol., 68, 1345-1352 (2004).

13) Yamamoto C., Takemoto H., Kuno K., Yamamoto D., Tsubura A., Kamata K., Hirata H., Yamamoto A., Kano H., Seki T., Inoue K., Hepatology, 30, 894-902 (1999).

14) Yamamoto C., Takemoto H., Kuno K., Yamamoto D., Nakai K., Baden T., Kamata K., Irata H., Watanabe T., Inoue K., Oncol. Rep., 8, 821824 (2001).

15) Han S. B., Kim H. M., Kim Y. H., Lee C. W., Jang E. S., Son K. H., Kim S. U., Kim Y. K., Int. J. Immunopharmacol., 20, 1-13 (1998).

16) Montaner B., Navarro S., Pique M., Vilaseca M., Martinell M., Giralt E., Gil J., Perez-Tomas R., Br. J. Pharmacol., 131, 585-593 (2000).

17) Melvin M. S., Tomlinson J. T., Saluta G. R., Kucera G. L., Lindquist N., Manderville R. A., J. Am. Chem. Soc., 122, 6333-6334 (2000).

18) Komatsu N., Oda T., Muramatsu T., J. Biochem. (Tokyo), 124, 1038 1044 (1998).

19) Benjamin E. N., Rich M., Terry R., Promega Notes Magazine, 64 13-17 (1997).

20) McKelvy-Martin V. J., Ho E. T., McKeown S. R., Johnston S. R., McCarthy P. J., Rahab N. F., Downes C. S., Mutagenesis, 13, 1-8 (1998).

21) Yoshimori T., Yamamoto A., Moriyama Y., Futai M., Tashiro Y., $J$. Biol. Chem., 266, 17707-17712 (1991).

22) Heyworth P. G., Curnute J. T., Nauseef W. M., Volpp B. D., Peason D. W., Rosen H., Clark R. A., J. Clin. Invest., 87, 352-356 (1991).

23) Allen R. C., Methods Enzymol., 133, 449—493 (1986).

24) Imada I., Sato E. F., Miyamoto M., Ichimori Y., Minamiyama Y., Konaka R., Inoue M., Anal. Biochem., 271, 53-58 (1999).

25) Llagostera E., Soto-Cerrato V., Montaner B., Perez-Tomas R., Ann. N.Y. Acad. Sci., 1010, 178-181 (2003).

26) Montaner B., Perez-Tomas R., Toxicol. Lett., 129, 93-98 (2002).

27) Yamamoto D., Uemura Y., Tanaka K., Nakai K., Yamamoto C., Takemoto H., Kamata K., Hirata H., Hioki K., Int. J. Cancer, 88, 121-128 (2000).

28) Hwang Y. S., Bethke P. C., Gubler F., Jones R. L., Plant J., 35, 154163 (2003).

29) Sato T., Konno H., Tanaka Y., Kataoka T., Nagai K., Wasserman H. H., Ohkuma S., J. Biol. Chem., 273, 21455-21462 (1998).

30) Tanigaki K., Sasaki S., Ohkuma S., FEBS Lett., 537, 79-84 (2003).

31) Manderville R. A., Curr. Med. Chem. Anti-Canc Agents, 1, 195-218 (2001).

32) Furstner A., Grabowski E. J., Chembiochem., 2, 706-709 (2001).

33) D'Alessio R., Bargiotti A., Carlini O., Colotta F., Ferrari M., Gnocchi P., Isetta A., Mongelli N., Motta P., Rossi A., Rossi M., Tibolla M., Vanotti E., J. Med. Chem., 43, 2557-2565 (2000).

34) Groemping Y., Lapouge K., Smerdon S. J., Rittinger K., Cell, 113, $343-355$ (2003)

35) Parthasarathy S., Santanam N., Curr. Opin. Lipidol., 5, 371-375 (1994). 